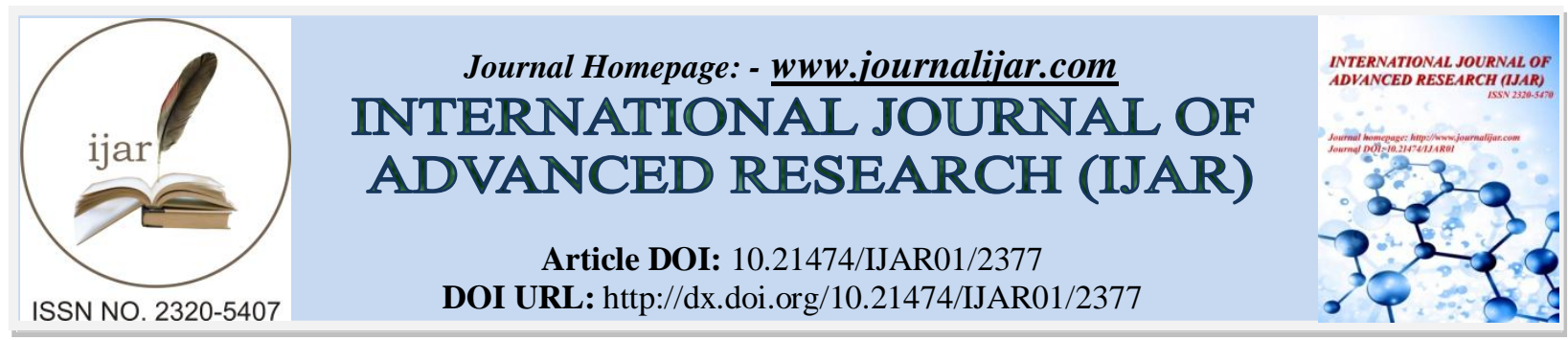

RESEARCH ARTICLE

\title{
SURVEY OF MANGROVES AND THEIR ASSOCIATES IN KEEZHAKARAI GROUP OF ISLANDS, GULF OF MANNAR BIOSPHERE RESERVE.
}

\section{S. Arunprabu, P. Dinesh and T. Ramanathan*.}

Centre of Advanced Study in Marine Biology, Faculty of Marine Sciences, Annamalai University, Parangipettai 608502, Tamil Nadu, India.

\section{Manuscript Info}

Manuscript History

Received: 19 October 2016

Final Accepted: 20 November 2016

Published: December 2016

Key words:-

Mangroves, Keezhakarai,

Pemphis acidula, Deforestation.

\section{Abstract}

Mangroves are among the most productive coastal ecosystems in the world. The Gulf of Mannar Marine Biosphere Reserve is unique to have very rare mangrove species. It consists of 4 group of Islands are Mandapam group Islands, Keezhakarai group of Islands, Vembar group of Islands and Tuticorin group of Islands. The present survey was conducted only in the Keezhakarai group of island. Totally 18 species were recorded in the study period including 4 mangroves and 14 mangrove associated plants. In Mangroves Endemic species Pemphis acidula was most dominant plant for all the stations. Six associates Pongamia pinnata, Suaeda maritima, Suaeda monoica, Thespesia populnea, Ipomoea pes-caprae and Sesuvium portulacastrum were observed as dominant species. The information generated from this study will serve as a baseline to develop adaptive management strategies in anticipation of sea-level rise, set conservation priorities, monitor deforestation and forest degradation, improve terrestrial carbon accounting and quantify the role of mangrove forests in saving lives and property from natural disasters such as tsunamis.

Copy Right, IJAR, 2016,. All rights reserved.

\section{Introduction:-}

Mangroves are among the most productive coastal ecosystems in the world. They are confined to the tropics and subtropics, which dominate approximately $75 \%$ of the world's coastline between $25^{\circ} \mathrm{N}$ and $25^{\circ} \mathrm{S}$ and are estimated to cover an area of 1.7 to $2.0 \times 10^{5} \mathrm{~km}^{2}$ (Borges et al., 2003). Mangroves are trees and shrubs that grow in saline coastal habitats. Mangroves are a taxonomically diverse group of salt-tolerant, mainly arboreal, flowering plants (Ellison and Stoddart, 1991). They fall into two groups according to their habitats in nature: true mangroves and mangrove associates. True mangroves refer to species that specifically grow in intertidal zones, while mangrove associates are capable of occurring in either littoral or terrestrial habitats. Mangrove formations depend on terrestrial and tidal waters for their nourishment and silt deposits from upland erosion as substrate for support (Kathiresan, 2003). Substances in mangroves have long been used in folk medicine to treat diseases (Bandaranayake, 1998). Mangrove habitats of India have been facing tremendous threats due to indiscriminate exploitation of mangrove resources for multiple uses like fodder, fuel wood, timber for building material, alcohol, paper, charcoal and medicine (Upadhyay et al., 2002).

\section{Corresponding Author:- T. Ramanathan.}

Address:- Centre of Advanced Study in Marine Biology, Faculty of Marine Sciences, Annamalai University, Parangipettai - 608502, Tamil Nadu, India. 
The Gulf of Mannar Biosphere Reserve is the region in far south of Tamil Nadu State, harbouring mangroves with diversity. It is believed that the Gulf of Mannar was once covered with thick mangrove forests all along the State. Their remnants as relics are seen even now. Of the 21 islands, 11 are colonized with luxuriant mangrove ecosystems and these islands are Kurusadai island, Pullivasal island, Poomarichan island, Manoliputti island, Manoli island, Hare island, Mullai island, Valai island, Talaiyari island, Appa island and Nallathanni island.

The Gulf of Mannar Marine Biosphere Reserve is unique to have very rare mangrove species. One such is Pemphis acidula which is endemic to Peninsular India and restricted to coral sand of open sea-face, notably at Manauli, Manaulipatti, Poomarichan and Hare Islands. In Tamil Nadu, Cerips tagal is found to be present only in the Gulf of Mannar region. This species has high percentage of tannin in its bark. Medicinally it is used to cure malaria and also prevents haemorrhage. The whole plant has antidiabetic property and is also used in treatment of malignant ulcers . Nothing is known about floral biology and pollinators of those rare species in the Gulf of Mannar, although such information is a prerequisite for restoration process (Tomlinson, 1979).

There is no previous survey of mangroves for the whole of the Gulf of Mannar nor are there any bench mark studies on the flora. The present survey was conducted only in the Keezhakarai group of island.

\section{Materials and Methods:-}

The Gulf of Mannar Biosphere Reserve situated in south of Tamil Nadu, India. It consists of 4 group of Islands are Mandapam group of Islands, Keezhakarai group of Islands, Vembar group of Islands and Tuticorin group of Islands. In Keezhakarai group of Islands we survived 6 Islands viz., Mulli, Valai, Talaiyari, Appa, Valimunai and Anaipar. The coastal line in Tamil Nadu represents varied geomorphological features in the form of long beaches, sometimes intercepted by rocks forming attractive beaches.

\section{Data collection and duration:-}

The areas where mangroves and mangrove associated vegetation exists in Keezhakarai group of Islands were first identified and documented. For the assessment of present biodiversity status, the mangroves, mangrove associated vegetations existing around the study area were considered for identification. Regular surveys were made throughout the Islands to explore the successful results of the true mangroves and their associates. The mangroves and mangrove associated vegetation were plucked during their flowering and fruiting seasons for identification and took photographs with the help of camera. The nomenclature of the specimens followed Gamble (1957) and Matthew (1983). Plant specimens were collected whenever identification was not possible in the field. The collected specimens were identified with the help of the publications (Rajendran and BaskaraSanjeevi, 2004; Ramanathan, 1997). Nomenclatures of the identified species were checked with the International Plant Naming Index (IPNI).

\section{Results:-}

Totally 18 species were recorded in the study period including 4 mangroves and 14 mangrove associated plants. In Mangroves Endemic species Pemphis acidula was most dominant plant for all the stations. Six associates Pongamiapinnata, Suaeda maritima, Suaeda monoica, Thespesiapopulnea, Ipomoea pes-capra and Sesuvium portulacastrum were observed as dominant species (Table. 1).

All mangrove plants were observed in Talaiyari Island (4) followed by Valai and Appa Island (3) were noted in Keezhakarai group of Islands in Gulf of Mannar. Very least abundance of mangrove plants was recorded in Mulli, Valimunai and Anaipar Island (2).

Table. 1:- Distribution of mangroves and their associates in Keezhakarai group of Islands in Gulf of mannar.

\begin{tabular}{|c|c|c|c|c|c|c|c|}
\hline S. No. & Species & Mulli & Valai & Talaiyari & Appa & Valimunai & Anaipar \\
\hline & & \multicolumn{6}{|c|}{ Mangroves } \\
\hline 1. & Avicennia marina & ++ & + & +++ & + & + & + \\
\hline 2. & Pemphis acidula & +++ & ++++ & ++++ & ++ & ++ & ++ \\
\hline 3. & Rhizophora mucronata & - & - & + & - & - & - \\
\hline \multirow[t]{2}{*}{4.} & Excoecaria agallocha & - & + & + & + & - & - \\
\hline & & \multicolumn{6}{|c|}{ Mangrove Associates } \\
\hline 5. & Catharanthus roses & - & - & + & + & - & - \\
\hline 6. & Derris trifoliate & - & - & + & + & + & - \\
\hline
\end{tabular}




\begin{tabular}{|c|l|c|c|c|c|c|c|}
\hline 7. & Pongamia pinnata & ++ & ++ & ++ & +++ & ++ & ++ \\
\hline 8. & Suaeda maritima & ++ & ++ & ++++ & + & + & + \\
\hline 9. & Suaeda monoica & + & + & +++ & + & + & + \\
\hline 10. & Salicornia brachiate & - & - & ++ & - & - & - \\
\hline 11. & Thespesia populnea & ++ & ++ & ++++ & ++ & ++ & ++ \\
\hline 12. & Helitropium curassavicum & - & + & + & + & + & + \\
\hline 13. & Ipomoea pes-capra & + & +++ & +++ & ++ & + & + \\
\hline 14. & Sesuvium portulacastrum & + & +++ & +++ & +++ & ++ & ++ \\
\hline 15. & Calotropis gigantea & - & - & + & + & - & - \\
\hline 16. & Arthrocnemum indicum & + & + & +++ & - & - & - \\
\hline 17. & Spinifex littoreus & - & - & + & + & + & + \\
\hline 18. & Spinifex sericeus & - & - & + & + & + & - \\
\hline & \multicolumn{1}{|l|}{ Total } & 9 & 11 & 18 & 15 & 12 & 10 \\
\hline
\end{tabular}

-: Not recorded; +: present (1-3 sites); ++: Co abundant (4-6 sites); +++: Abundant (7-9 sites); ++++: Dominant (above 9 sites)

\section{Discussion:-}

A total 39 mangroves species were identified from India (Kathiresan, 1999). Tomlinson (1986) reported 60 species mangrove associates belonging to 46 genera and 27 families that exist in the world mangroves. Along the east coast, the least number of mangrove species is present in Tamil Nadu (Deshmukh and Mahalingam, 1991). Our present study indicated that 4 Mangrove species and 14 associated species were present. Analysis of the distribution of true mangrove species in different Tamil Nadu mangrove wetlands indicates that Acanthus ilicifolius, Aegiceras corniculatum, Avicennia marina, Bruguiera cylindrica, Ceriops decandra, Excoecaria agallocha, Lumnitzera racemosa, Rhizophora apicuata, Avicennia marina are common to all the mangroves of Tamil Nadu. The Tamil $\mathrm{Nadu}$ is also characterized by the presence of a natural hybrid of Rhizophora species. Rhizophora annamalayana and Xylocarpus mekongensis presented in this Vellar estuaries and pichavaram (Kathiresan, 2003).

\section{Conclusion:-}

Plants have a long history of use in the treatment of several diseases. The approach for minimizing unwanted toxicity is to employ newer natural products that may act by different and distinct mechanism and precipitate less serious effects. A number of plant or other natural product extracts have been studied for leading to the development of several clinically useful agents.

Mangroves are under constant flux due to both natural (e.g. erosion, aggradations) and anthropogenic forces. In the last three decades, forest losses because of anthropogenic factors have increased significantly. The remaining mangrove forests are under immense pressure from clear-cutting, land-use change, hydrological alterations, chemical spill and climate change. In the future, sea-level rise could be the biggest threat to mangrove ecosystems. The information generated from this study will serve as a baseline to develop adaptive management strategies in anticipation of sea-level rise, set conservation priorities, monitor deforestation and forest degradation, improve terrestrial carbon accounting and quantify the role of mangrove forests in saving lives and property from natural disasters such as tsunamis.

\section{Reference:-}

1. Borges, A. V., Djenidi, S., Lacroix, G., The 'ate, J., Delille, B. and Frankignoulle, M. (2003): Atmospheric CO2 flux from mangrove surrounding waters, Geophys. Res. Lett., 30(11): 1558.

2. Ellison, J.C. and Stoddart, D.R. (1991): Mangrove ecosystem collapse during predicted sea-level rise: Holocene analogues and implications. Journal of Coastal Research., 7: 151-165.

3. Kathiresan, K. ( 2003): How do mangrove forests induce sedimentation? Rev. Biol. Trop., 51: 355-360.

4. Bandaranayake, W.M. (1998): Traditional and medicinal uses of mangroves. Mang. \& Salt Marsh, .2: $133-48$.

5. Tomlinson, P.B. (1986): The Botany of Mangroves. Cambridge University Press, Cambridge, pp. $62-115$.

6. Gamble J.S. (1957). Flora of the Presidency of Madras, Botanical Survey of India, Calcutta.

7. Matthew K.M. (1983): The Flora of the Tamilnadu Carnatic. The Rapinat Herbarium, Tiruchirapalli. 
8. Rajendran, N., Baskara Sanjeevi, S. (2004): Flowering Plants and Ferns in Mangrove Ecosystem of India, An Identification Manual. Environmental Information System (ENVIS), Centre for Advanced study in Marine Biology, Annamalai University, India.

9. Ramanathan, A.L. (1997): Sediment characteristics of the Pichavaram mangrove environment, southeast coast of India. Ind. J. Mar. Sci., 26: 319-322.

10. Kathiresan, K. (1999): Impact of mangrove biodiversity on associated fishery resources and fishers' income. A project final report submitted to WWF, Washington DC.: pp.142.

11. Deshmukh, S.V. (1991): Mangroves of India: Status report. In: Deshmukh S V, Mahalingam R, eds. A Global Network of Mangrove Genetic Resource Centres Project Formulation Workshop. Madras, India, 15-25.

12. Kathiresan, K. (2003): How do mangrove forests induce sedimentation?. Revista de Biologia Tropical., 51(2): 355-360.

13. Upadhyay, V.P., Ranjan, R. and Singh, J.S. (2002): Human mangrove conflicts: The way out. Current Science., 83: 1328-1336. 